\title{
Insight into brain-to-brain, brain-to- humanoid and brain- to-things communication modelling using cyborg and IoT
}

\author{
Sadique Shaikh* and Safina Khan \\ KYDSC Trust's, Institute of Management \& Science (IMS), Bhusawal, Maharastra, India
}

\begin{abstract}
Brain-to-Brain, Brain-to- Humanoid and Brain-to-Things Communication are the future reality which interconnect all human brains, humanoids and non-living organisms/things using IoT (Internet of Things), Satellites, Bigdata and Cyborg BCI interfaces worldwide to establish communication using RFID (Radio Frequency Identification) and Virtual signals based on BCI (Brain Computer Interfaces) band Neuromodulation. When this happen possible (research in progress) in the world no one communicate physically with mouth and will have ability to established instant communication without cell phones and mobile worldwide direct using IoT with Super intelligence streaming from Bigdata Servers available in IoT using USN (Ubiquitous Sensing Network) and RFIDs. This paradigm shift transforms human race on planet earth from Type-0 civilization to Type-I or Type-II technologically advanced civilization. To understand above mentioned you can consider the example of my ever-close movie "Avatar". You have seen Human Brain Synch with Neuromodulation streaming to Pandora Planet Alien form with dream. Even you have seen all Intelligence Creatures, animals, birds, trees and plants interconnected which each other on that planet Pandora. I have exhibited three models to give your idea about it labeled as Brain-to-Brain Communication Model (BBCM), Brain-to Humanoid (Robotics) Communication Model (BHCM) and Brain-toThings (All living \& Non-living things) Communication Model (BTCM).
\end{abstract}

\section{Brain-to-Brain Communication Model (BBCM)}

Above model display how Brain-to-Brain communication possible to establish in near future. Here two or many brains continue can change in source to destination alternatively for communication and data/information exchange from one to another brain. All the neurons signal of brain changes to information using BCI and to send it to another brain neuromodulation use. This would be similar to regular electronic modulation and demodulation but instead of electrons information encoded and decoded using neurons virtual brain to brain modulated signals. Brain-to-Brain near field communication established using low frequency transmitter and receiver but to establish Brainto-Brain communication between two remote human brains located worldwide we need RFID Antenna and Satellite based IoT (Figure 1).

\section{Brain-to Humanoid Communication Model (BHCM)}

This is my second model to showcase future possibility to establish communication between human brain and humanoid robots bionic brain using additional requirements to humanoid side and human side. Since humanoid processing electronic or optical based, hence brain neurons signal converted into information using BCI and cybermatic and neuro-information converted into equivalent electrical or optical signals and then fed to modulation encoding. At the humanoid side signal received and processed by humanoid interfaces and given Ultra Artificial Intelligence (UAI) based bionic brain. When communication from Humanoid Bionic-to-Human Brain at that time humanoid need electrons/photons to neurons conversion (Figure 2).

\section{Brain-to-Things Communication Model (BTCM)}

My last model depicted how communication possible between human brains and living/non-living things. In this case human brain side explanation remains same as to BHCM human brain source side but change to considering destination as various Things. Hence everything has its own unique RFID to explore and establish communication worldwide with sensing antennas and USN using IoT, Bigdata and satellites. Here after/before encoding/decoding as source/destination we need to engineer signal conditioning units which stabilized various signals forms and send RFID interface to convert send signal to process by living/non-living things with RFID and, Antenna \& Processing H/Ws (Figure 3).

\section{Conclusion}

I have displayed three important models BBCM, BHCM and BTCM to understand you what future communication forms are and how it would be possible. I have discussed with models Brain-to-Brain, Brainto-Humanoid and Brain-to-Things communication patterns. I also like to state these models possible hybridize as Humanoid-to-Things, Things-to-Things and Humanoid-to-Humanoid communication using polymorphism forms of source and destination sides interchange of these three models.

${ }^{*}$ Correspondence to: Sadique Shaikh, KYDSC Trust's, Institute of Management \& Science (IMS), Bhusawal, Maharashtra, India, E-mail: sids_nsk@rediffmail.com

Key words: $B B C M, B H C M, B T C M, B C I$, humanoid, IoT, bigdata, USN, RFID, neuromodulation, cyborg, cybermatic

Received: September 26, 2018; Accepted: October 04, 2018; Published: October 09, 2018 


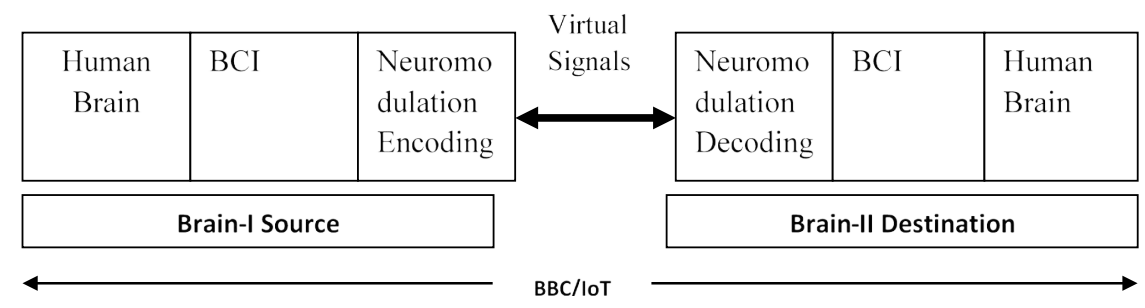

Figure 1. Brain-to-Brain Communication Model (BBCM)

\begin{tabular}{|c|c|c|c|c|c|c|c|c|}
\hline $\begin{array}{l}\text { Human } \\
\text { Brain }\end{array}$ & $\mathrm{BCI}$ & $\begin{array}{l}\text { Neuron- } \\
\text { Electron } \\
\text { s/Photo } \\
\text { ns } \\
\text { Convers } \\
\text { ion }\end{array}$ & $\begin{array}{l}\text { Electron } \\
\text { ic/Optic } \\
\text { al } \\
\text { Modulat } \\
\text { ion } \\
\text { Encodin } \\
\text { g }\end{array}$ & $\begin{array}{l}\text { Neuron, } \\
\text { Electro, } \\
\text { optical } \\
\text { Signals }\end{array}$ & $\begin{array}{l}\text { Electron } \\
\text { ic/Optic } \\
\text { al } \\
\text { Modulat } \\
\text { ion } \\
\text { Encodin } \\
\mathrm{g}\end{array}$ & $\begin{array}{l}\text { Electro } \\
\mathrm{ns} / \mathrm{Phot} \\
\text { ons to } \\
\text { Neuron } \\
\mathrm{s} \\
\text { Conver } \\
\text { sion }\end{array}$ & $\begin{array}{l}\text { Human } \\
\text { oid } \\
\text { Interfac } \\
\text { es }\end{array}$ & $\begin{array}{l}\text { Ultra- } \\
\text { Artificial } \\
\text { intelligen } \\
\text { ce/ Bionic } \\
\text { Brain }\end{array}$ \\
\hline \multicolumn{4}{|c|}{ Human Brain Source } & & \multicolumn{4}{|c|}{ Humanoid Bionic Brain Destination } \\
\hline
\end{tabular}

Figure 2. Brain-to Humanoid Communication Model (BHCM)

\begin{tabular}{|c|c|c|c|c|c|c|c|c|}
\hline $\begin{array}{l}\text { Human } \\
\text { Brain }\end{array}$ & $\mathrm{BCI}$ & $\begin{array}{l}\text { Neuron- } \\
\text { Electro } \\
\text { ns/Phot } \\
\text { ons } \\
\text { Convers } \\
\text { ion }\end{array}$ & $\begin{array}{l}\text { Electronic } \\
\text { /Optical } \\
\text { Modulatio } \\
\mathrm{n} \\
\text { Encoding } \\
\text { with } \\
\text { RFIDs }\end{array}$ & $\begin{array}{l}\text { Neuron } \\
\text { Electro, } \\
\text { optical } \\
\text { Signals }\end{array}$ & $\begin{array}{l}\text { Electroni } \\
\text { c/Optical } \\
\text { Modulati } \\
\text { on } \\
\text { Encodin } \\
\text { g with } \\
\text { RFID }\end{array}$ & $\begin{array}{l}\text { Signal } \\
\text { Conver } \\
\text { sion } \\
\text { Unit }\end{array}$ & $\begin{array}{l}\text { RFIDs } \\
\text { Interfac } \\
\text { es }\end{array}$ & $\begin{array}{l}\text { Living/No } \\
\text { n-living } \\
\text { Things } \\
\text { with } \\
\text { RFID and, } \\
\text { Antenna } \\
\& \\
\text { Processin } \\
\therefore \quad \mathbf{H} / \mathbf{s} / \mathrm{c}\end{array}$ \\
\hline \multicolumn{4}{|c|}{ Human Brain Source } & & \multicolumn{4}{|c|}{ Various Things Destination } \\
\hline
\end{tabular}

Figure 3. Brain-to-Things Communication Model (BTCM)

Copyright: (C2018 Shaikh S. This is an open-access article distributed under the terms of the Creative Commons Attribution License, which permits unrestricted use, distribution, and reproduction in any medium, provided the original author and source are credited. 